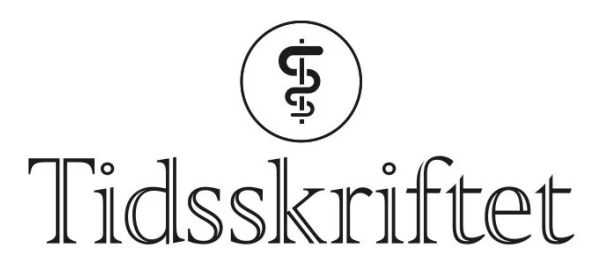

DEN NORSKE LEGEFORENING

\title{
Grundig om stamceller og stamcelleforskning
}

ANMELDELSER

\section{KNUT LISETH}

Haukeland universitetssykehus

Avdeling for immunologi og transfusjonsmedisin

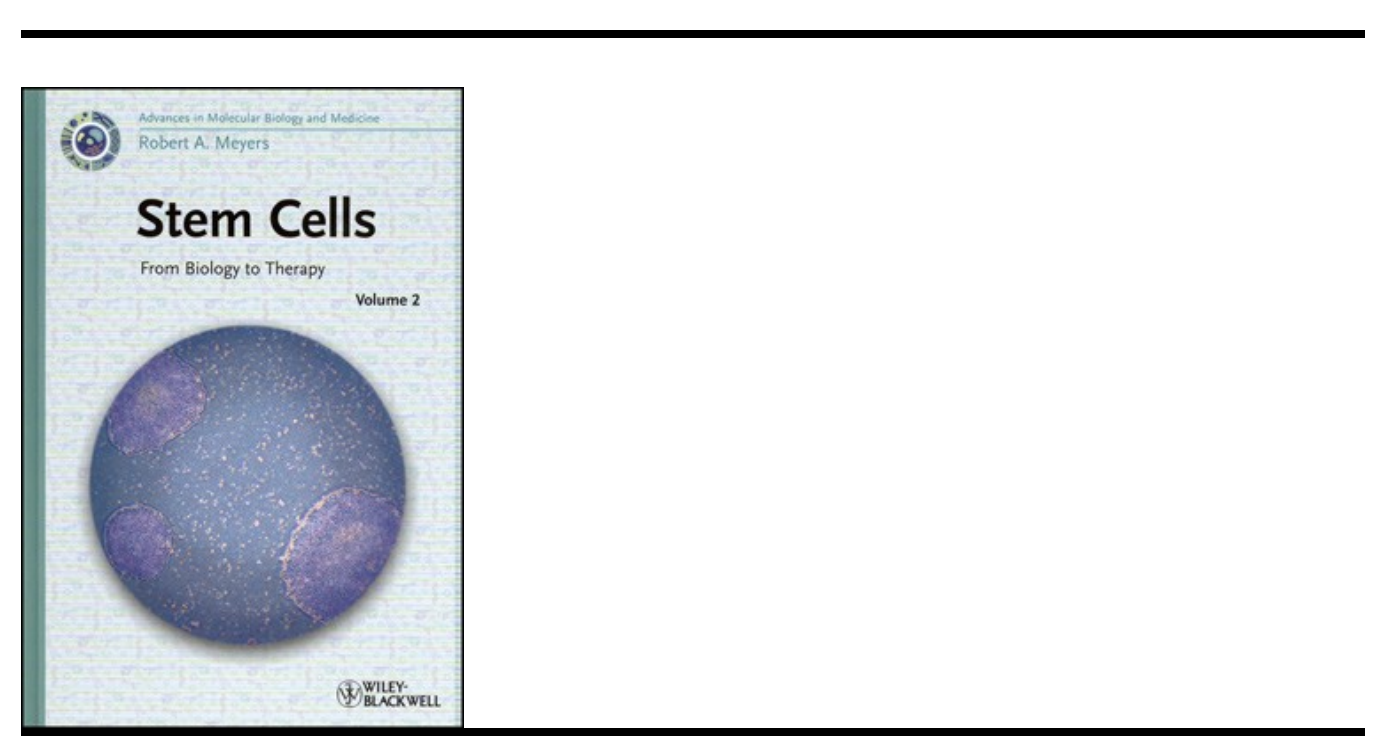

Meyers, Robert A.

Stem cells

From biology to therapy. 2 bd. 778 s, tab, ill. Chichester: Wiley-Blackwell, 2013. Pris GBP 205

ISBN 978-3-527-32925-0

Denne utgivelsen består av to bind og er av meget høy kvalitet. Bøkene er skrevet av fremstående eksperter på området, blant annet fem nobelprisvinnere.

Verket består av til sammen 26 kapitler og er delt inn i fire hoveddeler: basal biologi, laboratoriemetoder, stamcelleterapi og stamceller og sykdom.

De 26 kapitlene er skrevet av forskjellige forfattere, og hvert kapittel har egne referanser. Hvert kapittel kan leses som en selvstendig oversiktsartikkel. Redaktøren har gjort en god jobb med å begrense overlapping mellom de forskjellige kapitlene, samtidig som hele 
temaet stamceller fremstår som godt dekket.

Bøkene er som nevnt delt inn i fire hoveddeler, og jeg vil anta at det er delene om stamcelleterapi og stamceller og sykdom som vil interessere flest leger. Delen om stamcelleterapi inneholder blant annet spennende kapitler om stamcelleforskning ved Parkinsons sykdom, hemoglobinopatier og ryggmargsskader. I disse kapitlene forklarer forfatterne hvorfor stamcellebehandling kan ha potensial for store medisinske gjennombrudd ved disse diagnosene, samtidig som de klargjør hvilke vanskeligheter som gjenstår før stamcelleterapi kan bli mer enn eksperimentell behandling ved disse diagnosene.

I delen om stamceller og sykdom konsentrerer forfatterne seg om vår viten om kreftstamceller. Denne delen kan være nyttig for mange som ønsker å få en dypere forståelse for behandlingen av metastasert kreftsykdom, og hvorfor cellegift ikke alltid er effektivt.

Det er relativt få figurer og tabeller, men illustrasjonene som er tatt med, er oversiktlige og klargjørende.

Jeg kan anbefale bøkene for avdelinger og enkeltpersoner som ønsker et oppslagsverk, eller som ønsker å sette seg grundig inn i temaet stamceller og få et overblikk over den omfattende forskningen som er gjort på stamceller. Jeg vil ikke anbefale dem til personer som ønsker å få et innblikk i dette store temaet. Til det er detaljrikdommen for stor, og teksten er primært skrevet med tanke på personer som allerede har kjennskap til temaet. Det kan også innvendes at det kan være vanskelig å se de store linjene innen temaet stamcelleforskning første gang man leser. Prisen på over 2 ooo kroner er relativt høy, men som et oppdatert oppslagsverk over temaet stamceller vil jeg hevde at de to bindene kan betraktes som en gullstandard.

Publisert: 14. januar 2014. Tidsskr Nor Legeforen. DOI: 10.4045/tidsskr.13.1309

(C) Tidsskrift for Den norske legeforening 2023. Lastet ned fra tidsskriftet.no 26. april 2023. 